\title{
The Roles of L1 and Lexical Aspect in the Acquisition of Tense-Aspect by Thai Learners of English
}

\author{
Boonjeera Chiravate ${ }^{1}$ \\ ${ }^{1}$ Department of English, Faculty of Arts, Silpakorn University, Thailand \\ Corespondence: Boonjeera Chiravate, Department of English, Faculty of Arts, Silpakorn University, Thailand. \\ E-mail: chiravate@gmail.com
}

Received: June 23, 2018 Accepted: July 23, 2018 Online Published: July 25, 18

doi: 10.5539/elt.v11n8p111 URL: http://doi.org/10.5539/elt.v11n8p111

\begin{abstract}
Investigating the L2 temporality, most previous studies within the Aspect Hypothesis framework focused on the basic meanings or prototypical uses of past morphology. The present study, however, including other less prototypical uses of past morphology, addresses 2 questions: (i) how the uses of simple past and past progressive morphology change as learners become more proficient in their target language; (ii) to what extent lexical aspectual class and L1 influence the uses of simple past and past progressive morphology. Using a cloze test as an elicitation task, this study analyzes data from 5 groups of Thai EFL learners at different proficiency levels. Results show that learners use past morphology more accurately as their L2 proficiency levels increase. The tense-aspect marking was, however, affected by lexical aspectual class. Learners first use simple past form on telic verbs, eventually extending its use to atelic verbs. The progressive form, on other hand, begins with atelic verbs and then extends to telic verbs. All learner groups, however, exhibit a higher rate of appropriate use of past morphology in the more prototypical uses than in the less prototypical uses. Additionally, L1 plays an important role in the tense-aspect marking. Learners at different proficiency levels, however, use different L1-influenced forms, suggesting that L1 influence is constrained by L2 development. Contributing to the body of research on L2 tense-aspect, this study shed light on the nature of difficulty learners experience in developing L2 tense-aspect system.
\end{abstract}

Keywords: aspect hypothesis, tense- aspect, Thai EFL learners, L1 influence

\section{Introduction}

\subsection{The Problem}

It has consistently been discussed that at the early stages of L2 acquisition, learners tend to use verbal morphology to mark lexical aspectual distinction rather than temporal distinction. For instance, L2 English learners use simple past marking on telic verbs more frequently than atelic verbs. This phenomenon of limiting verbal morphology to a restricted class of verbs, according to their aspectual properties is captured by the Aspect Hypothesis.

Since the Aspect Hypothesis is predicted to be universal, most research has investigated learners' developmental patterns in different languages. For instance, Andersen (1991), Salaberry (1999), Rohde (1996), Dittmar (1981), investigated learners whose L1 and L2 are both [+tense] languages. Sato (1990), Bayley (1991, 1994), Giacalone Ramat and Banfi (1990) and Sriphrom (2014) have investigated a group of [-tense] L1 speakers learning [+tense] L2 (as cited in Gabriele, 2005: 74).

Investigating the influence of lexical aspect on the use of tense forms, most of the earlier studies focus only on the prototypical uses of past morphology and put aside other uses. The present study, including both the prototypical uses and other less prototypical uses of past morphology, examines how the use of simple past and past progressive morphology changes as learners become more proficient in their target language and investigates the extent to which lexical aspect and L1 influence their use of simple past and past progressive morphology.

\subsection{Previous Studies}

To begin with, a summary of earlier studies on temporal expression is provided. First, the concepts of tense and aspect are summarized. Then, we will briefly discuss the Thai and English temporal systems. Finally, we revise 
studies on the Aspect Hypothesis and roles of L1 in the acquisition of L2 tense-aspect system.

\subsubsection{Tense and Aspect}

Both tense and aspect (henceforth referred to as tense-aspect) are grammatical categories that refer to the notion of temporality. Tense specifies a time at which the corresponding tenseless sentence is true. For example, the sentence John often cooked, uttered at a speech time $t$. Past expresses that there is a period of time before the the speect time $t$ at which the sentence John often cook is true. Past indicates that the event at issue precedes speech time; future indicates that it follows speech time (Strazny, 2005: 1088). Aspect, on the other hand, has to do with the internal temporal structure of the event the verb refers to, with the perspective the speaker adopts toward the structure of the event, or with both of these (Strazny, 2005: 93). For instance, in John was cooking (when Mary came in), the inherently unbounded verb to cook and the progressive indicate that an event is still in progress, relative to the reference time given through Mary's coming in. Aspect is usually divided into two categories: grammatical aspect and lexical aspect. Lexical aspect refers to features inherent in a particular a situation as expressed by a predicate. Vendler (1967) distinguished 4 lexical aspectual classes: state, activity, accomplishment and achievement. Capturing the 4 aspectual classes, Comrie (1976) subsequently pointed out 3 basic semantic distinction: stative vs. dynamic, telic vs. atelic, and punctual vs. durative. States and activities are distinguished by the [dynamic] feature: states are [-dynamic], whereas activities are [+dynamic]. Activities and accomplishments are distinguished by the [telicity] feature: Activities are [-telic], whereas accomplishments are [+telic]. Finally the subtle distinction between accomplishments and achievements is realized through the [punctual] feature: Accomplishments are [-punctual], whereas achievements are [+punctual]. Table 1 demonstrates the semantic features of lexical aspectual classes.

Table 1. Semantic features of lexical aspectual classes

\begin{tabular}{|c|c|c|c|c|}
\hline \multirow{2}{*}{ Lexical aspectual class } & \multicolumn{3}{|c|}{ Semantic feature } & \multirow{2}{*}{ Example } \\
\hline & Dynamic & Telic & Punctual & \\
\hline State & - & - & - & $\begin{array}{l}\text { She lived in Bangkok. } \\
\text { She liked vegetable. } \\
\text { It sounded good. }\end{array}$ \\
\hline Activity & + & - & - & $\begin{array}{l}\text { She sang beautifully. } \\
\text { She ran down the stairs. } \\
\text { They played tennis. }\end{array}$ \\
\hline Accomplishment & + & + & - & $\begin{array}{l}\text { He wrote a letter. } \\
\text { He drew a circle. } \\
\text { They built a house. }\end{array}$ \\
\hline Achievement & + & + & + & $\begin{array}{l}\text { He found a wallet. } \\
\text { He won the race. } \\
\text { I arrived in NY at } 8 .\end{array}$ \\
\hline
\end{tabular}

Grammatical aspect, on the other hand, is usually encoded by inflectional verbal morphology. Grammatical aspect is divided into two categories: perfective and imperfective. Basically, in using the perfective aspect, the speaker looks onto an event as an undivided whole, often focusing on its completion. From the imperfective perspective, the speaker views the event as an ongoing process. In English the imperfective one occurs in sentences such as (1a) whereas the perfective one is expressed in sentences like (1b).

(1) a. She was writing. / She used to write. (imperfective)

b. She wrote. (perfective)

Languages, however, do not always show a fully developed perfective-imperfective distinction. In the following section, it will be discussed how Thai and English differ in expressing tense-aspect.

\subsubsection{The Thai and English Temporal System}

English and Thai differ in their realization of tense and aspect. English has verbal morphology for tense-aspect. In the simple present, a zero morpheme (Ø) produces a non-progressive reading when it goes with a state but a 
habitual reading when it goes with a dynamic verb, as in (2a) and (2b), respectively.
(2) a. Mary lives in Bangkok.
(non-progressive)
b. They play tennis.
(habitual)

The simple past usually gives a terminative or completive reading to a situation located in the past. For example, the most likely interpretation for a [-telic] state in (3a) is that Mary lived in Bangkok in the past and she no longer lives there (terminative reading). Similarly for [+telic] situation like (3b), the interpretation is that the house has been completed and is already there (completive reading). Therefore, the simple past tense is a combination of past time location of a unitary situation and perfective aspect.
(3) a. Mary lived in Bangkok.
(terminative)
b. They built a house.
(completive)

Although the perfective aspect (speakers' view on a unitary situation as an undivided whole) is the typical meaning associated with the simple past form, the simple past form, when interacting with activity verbs, may express imperfective aspects. For example, by (4a), the event of playing football is viewed as a regular action over an extended period of time. The same goes for the be+-ing form, as illustrated by ( $4 \mathrm{~b})$ where the event of running is viewed as a repeated action over an extended period of time. In this case, the simple past and be+-ing, therefore, produces an habitual reading, which is a concept of the imperfective aspect.
(4) a. We played football when we were children.
(habitual)
b. He is running every morning at $6 \mathrm{AM}$.
(habitual)

As regards the $b e+-i n g$ form, although it usually occurs with [+dynamic, +/-telic, -punctual] verbs, (i.e. activity and accomplishment), it may also occur with some [+dynamic, +telic, +punctual] verbs (i.e. achievement) (Smith, 1991, as cited in Gabriele, 2005: 18). The aspectual meaning, however, is not the process or action-in-progress as in (5a). To illustrate, (5b) means that he coughed repeatedly on a single occasion.
(5) a. Bill is singing.
(process)
b. Bill is coughing.
(iterative)

Nevertheless, the iterative meaning, is not the only aspectual reading resulting from the interaction of the be+-ing form and an achievement verb. As illustrated in (6), the be+-ing indicates that the event of waking up and arriving are about to happen. This suggests that the be+-ing form, when occurring with some achievement verbs, may express preliminary stages of an event or a process leading up to an endpoint or the so-called futurate reading (Andersen \& Shirai, 1996; Gabriele, 2005: 41).
(6) a. She is waking up.
(futurate)
b. The plane is arriving.
(futurate)

In English, therefore, the simple past morphology produces not only the perfective aspect but also the imperfective one (habitual past). Similarly, the be+-ing form produces not only the reading of process, but also other imperfective readings (i.e., iterative, futurate and habitual). The aspectual meaning, therefore, is determined by various sources including the lexical semantics of the verb phrase, verbal morphology and the interaction between the two.

On the contrary, there is neither morphological encoding of tense nor grammatical aspects in Thai. Whereas temporal locations of events are determined by pragmatic devices (e.g., context clues and chronological order in narration) and lexical expressions (e.g., yesterday, last month, the next year), Thai has a number of aspect markers such as khoey, khamlang, yuu and laew to express different ways of viewing the events, as shown in Table 2.

Table 2. Thai aspectual markers

\begin{tabular}{ll}
\hline Aspectual marker & Aspectual meaning \\
\hline khoey & existential / experiential perfect \\
khamlang & progressive \\
yuu & habitual / non-progressive \\
laew & inchoative / transition of a situation (definite/indefinite past) \\
\hline
\end{tabular}


To illustrate, khoey is considered to be a marker for "existential perfect" or "experiential perfect" (Boonyapatipark, 1983 as cited in Visonyanggoon, 2000) as it indicates that a situation occurs or a state holds at least once and that the experience of such a situation or state prevails up to the present time. Khamlang, on the other hand, conveys the idea that an event is on-going, and hence is a progressive marker. Unlike khamlang, yuu is considered to be an imperfective marker (Meepoe, 1996 as cited in Visonyanggoon, 2000) as it conveys habitual and nonprogressive meanings. Laew, on the other hand, standing for the property of abutment, is regarded as a marker for the shift or transition of a situation (Chiravate, 2002). When describing the termination of a situation, laew leaves implicit the subsequent situation. When describing the beginning of a situation, laew leaves implicit the previous situation. This makes laew function as both a marker for definite and indefinite pasts, in additional to a marker for inchoative aspect. Thai tense-system system, therefore, differs greatly from that of English.

\subsubsection{Studies on L2 Tense-Aspect Acquisition}

A large number of studies on the acquisition of L2 tense-aspect system have been conducted. One of the important findings from the studies in this area was known as the Aspect Hypothesis (Antinucci \& Miller 1976; Weist et al., 1984; Robinson, 1990; Andersen, 1991, Shirai \& Andersen, 1995, Andersen \& Shirai, 1996) which comprises the following four main descriptive claims:

1) Learners first use past marking (e.g. English) or perfective marking (e.g. Chinese, Spanish, etc.) on achievement and accomplishment verbs, eventually extending its use to activity and state verbs.

2) In languages that encode the perfective-imperfective distinction, imperfective past appears later thanperfective past, and the imperfective past marking begins with stative and activity verbs, then extending to accomplishment and achievement verbs.

3) In languages that have progressive aspect, progressive marking begins with activity verbs, then extends to accomplishment and achievement verbs.

4) Progressive marking is not only incorrectly overextended to stative verbs.

Focusing on claims (1) and (3), several studies on L2 English have been conducted. To begin with, Robinson (1995) analyzed oral interviews and written data from Spanish-speaking students studying English in Puerto Rico. It was found that learners tended to mark telic verbs with the past tense and activity verbs with progressive. The associations became stronger at higher levels of proficiency. In addition, learners tended to mark achievements with past tense even when they were referring to present or future events.

Bardovi-Harlig and Reynolds (1995), using a cloze test with short story passages, investigated the role of lexical aspect in the acquisition of tense and aspect. Their participants were learners of English from a wide range of L1 backgrounds. Results showed that learners were more accurate in providing the target past tense morphology for achievement and accomplishments as opposed to statives and activities. Additionally, the predicted association between progressive marking and activities was found. The past progressive, however, emerges after the present progressive in past time contexts. It is then suggested that the use of tensed progressive follows a stage in which a bare progressive form is used in past contexts.

Subsequently, analyzing oral and written narratives from learners of five different L1 backgrounds, Bardovi-Harlig (1998) found that learners' performance depended on the type of data elicitation task. In written narratives, learners performed equivalently with the achievement and accomplishment verbs. In oral narratives, however, the learner used the simple past morphology with achievement verbs significantly more than accomplishment verbs. Additionally, the predicted association between progressive marking and activities was found.

As regards the use of tense-aspect morphology by Thai learners of English, Sriphrom (2014) employed a cloze test and two written narratives. Analyzing data from 120 Thai learners of 3 different proficiency levels (i.e., limited, moderate and high), he found that the subjects used tense forms more accurately and more variably as their proficiency increased. Investigating the influence of lexical aspect, he found that across lexical aspects, the distribution of the simple past tense form in the narratives and the distribution of the past progressive tense form in the cloze test of all groups supports the Aspect Hypothesis.

A potential counterexample to the Aspect Hypothesis was discussed in Rohde (1996, 1997), Housen (2002) and Sirphrom and Ratitamkul (2014). Rohde $(1996,1997)$ analyzed the speech of young German-speaking children learning English as a foreign language. Although Rohde found the same bias for the past tense to mark achievements, there was a strong association for achievements in progressive as well. Housen (2002) also reported results not conforming to the Aspect Hypothesis. In Housen's study, French and Dutch learners of 
English were found to mark stative verbs in the past rather than dynamic verbs. Additionally, in Sriphrom and Ratitamkul's (2014) study, it was found that Thai learners of English used the simple past tense form equivalently with states and telic events, not corresponding to the predictions of the Aspect Hypothesis.

Although the Aspect Hypothesis has been investigated by a number of studies as mentioned above, most of the studies did not take all the uses of tense-aspect morphology into account. If we take Taylor's (1989) tense-aspect as a prototype category, consisting of good and marginal members, we can assume learners acquire prototypical members first, then gradually extend the scope to marginal members. Based on the learners' acquisition processes, Andersen and Shirai (1996) suggest that unitary past (a single event) is the prototypical use of past tense, whereas habitual past (repeated events over an extended period of time) is a less prototypical use of simple past morphology. With respect to the progressive aspect, the process meaning of the progressive (action in progress) is more basic than other meanings, which is illustrated in Table 3.

Table 3. Uses of simplepast and past progressive morphology

\begin{tabular}{ll}
\hline Past morphology & more prototypical $\rightarrow$ less prototypical \\
\hline Simple past & unitary $(\mathrm{Ach} \rightarrow \mathrm{Acc} \rightarrow \mathrm{Act} \rightarrow$ Sta $) \rightarrow$ habitual $($ Act $)$ \\
Past progressive & process $(\mathrm{Act} \rightarrow \mathrm{Acc}) \rightarrow$ iterative or futurate $($ Ach $) \rightarrow$ habitual (Act) \\
\hline
\end{tabular}

$($ Ach $=$ achievement; Acc $=$ accomplishment; Act $=$ activity; Sta $=$ state $)$.

However, examining L2 tense-aspect morphology, most of the previous studies focused on either the association between learners' use of simple past form and a single event or between the progressive form and the process meaning. The association between these tense-aspect morphology and other less prototypical uses is a relatively uninvestigated area.

\subsubsection{Studies on L1 Influence on L2 Tense-Aspect Acquisition}

Whether L1 influences the acquisition of the L2 tense-aspect system has been addressed in several studies. Collins (2002) investigated the degree to which adult Francophones ESL learners' use of tense-aspect markers in past contexts supported the predictions of the Aspect Hypothesis and the degree to which it showed L1 influence. Consistent with the Aspect Hypothesis, the learners were significantly more successful in using simple past with telics and struggled most with statives. In their nontarget responses, the learners preferred progressive for activities and present for statives. Furthermore, since the learners tend to associate nontarget perfect (a French-influenced form) with telics, L1 was claimed to play a role in the use of L2 tense-aspect markers.

Addressing L1 influence, Yang and Huang (2004), investigated the impact of the absence of grammatical tense in L1 on the acquisition of the tense-aspect system in L2. The language samples for their study were written narratives produced by the five groups of Chinese learners of English during class time within 50-60 minutes. Their findings are as follows. First, classroom instruction may force an early start of tense use. Secondly, the Chinese way of expressing temporality may reinforce the learners' initial tendencies of relying on pragmatic and lexical devices to indicate temporal locations. Thirdly, the early start of tense use and the L1 reinforcement of the learners' initial tendencies result in an extended period during which the learners' expression of temporality exhibits a very slow shift from depending more on pragmatic and lexical devices to depending more on grammatical devices. Similarly, in Wang's (2012) study of the acquisition of English tense and agreement morphology by L1 Malay and L1 Chinese learners of English, it was discussed that the absence of tense or agreement morphology in the L1 cause the learners to have difficulty with tense and agreement morphology in L2.

\section{Method}

\subsection{Research Questions}

Including not only the prototypical uses but also other less prototypical uses of tense-aspect morphology, this study investigates the roles of lexical aspect and L1 in Thai EFL learners' verbal morphology by addressing two research questions:

1). How does the use of simple past and past progressive morphology change as learners become more proficient in their target language?

2). To what extent do lexical aspect and L1 influence the use of simple past and past progressive morphology? 


\subsection{Subjects}

Participants were 100 Thai learners of English recruited from Silpakorn University. They were undergraduate students and had been studying English for average of 11.8 years. The participants were divided into 5 groups based ontheir scores from the two courses entitled 'English for Everyday Use' and 'English Skill Development' which the students had taken in their first year at the university. The scores from the two courses were calculated as $\mathrm{A}=4, \mathrm{~B}+=3.5, \mathrm{~B}=3, \mathrm{C}+=2.5, \mathrm{C}=2, \mathrm{D}+=1.5, \mathrm{D}=1$. The range of mean scores and their interpretation were demonstrated in Table 4.

Table 4. The participants of the study

\begin{tabular}{llll}
\hline Group & Range of mean scores & Proficiency level & $N$ \\
\hline 1 & $7.5-8.0$ & Advanced & 20 \\
2 & $6.5-7.0$ & Upper intermediate & 20 \\
3 & $4.5-6.0$ & Intermediate & 20 \\
4 & $3.5-4.0$ & Pre-intermediate & 20 \\
5 & $2.5-3.0$ & Beginning & 20 \\
Total & & & 100 \\
\hline
\end{tabular}

To increase the reliability of the separation procedure, students belonging to the gaps in the rank scale (i.e., 7.01-7.49, 6.01-6.49, 4.01-4.49, 3.01-3.49) were excluded.

\subsection{Instrument}

Instrument for this research is a cloze test consisting of 12 short passages which vary in length from 3 sentences to 5 sentences. The 12 passages contain 48 testing items and 8 distractors (56 in total). Of the 48 testing items, 26 items target the simple past morphology and 22 items target the past progressive morphology. The predicates are distributed across the 4 lexical aspectual classes. There are 14 achievements, 12 accomplishments, 16 activities, and 6 states. This is illustrated in Table 5.

Table 5. Testing items

\begin{tabular}{|c|c|c|c|}
\hline Lexical aspect & $\begin{array}{l}\text { Tense-aspect } \\
\text { marking }\end{array}$ & Aspectual reading & Verb Phrase \\
\hline \multirow{3}{*}{ Achievement } & $\begin{array}{l}\text { Past } \\
\text { simple }\end{array}$ & $\begin{array}{l}\text { unitary } \\
\text { (6 items) }\end{array}$ & $\begin{array}{l}\text { noticed a movie star sitting across her } \\
\text { recognized him straightaway } \\
\text { won the race } \\
\text { turned it off } \\
\text { decided not to be a farmer } \\
\text { found two diamond ring }\end{array}$ \\
\hline & \multirow{2}{*}{$\begin{array}{l}\text { Past } \\
\text { progressive }\end{array}$} & $\begin{array}{l}\text { iterative } \\
\text { (4 items) }\end{array}$ & $\begin{array}{l}\text { was kicking a ball around the yard } \\
\text { was coughing } \\
\text { was ringing } \\
\text { was jumping }\end{array}$ \\
\hline & & $\begin{array}{l}\text { approaching } \\
\text { end-point / futurate } \\
\text { (4 items) }\end{array}$ & $\begin{array}{l}\text { was reaching home } \\
\text { was arriving } \\
\text { was finishing her homework } \\
\text { was leaving the resort }\end{array}$ \\
\hline
\end{tabular}




\begin{tabular}{|c|c|c|c|}
\hline \multirow{2}{*}{ Acccomplishment } & $\begin{array}{l}\text { Past } \\
\text { simple }\end{array}$ & $\begin{array}{l}\text { unitary } \\
\text { (6 items) }\end{array}$ & $\begin{array}{l}\text { went to a bar } \\
\text { ate a slice of pizza } \\
\text { washed the car } \\
\text { bought the jacket } \\
\text { flew back home } \\
\text { wrote a paper }\end{array}$ \\
\hline & $\begin{array}{l}\text { Past } \\
\text { progressive }\end{array}$ & $\begin{array}{l}\text { process } \\
\text { (6 items) }\end{array}$ & $\begin{array}{l}\text { was walking to a fitting room } \\
\text { was trying on a jacket } \\
\text { was digging a hole } \\
\text { was driving to the dentist's } \\
\text { was buying a soda } \\
\text { was making a sandwich }\end{array}$ \\
\hline \multirow{4}{*}{ Activity } & \multirow{2}{*}{$\begin{array}{l}\text { Past } \\
\text { simple }\end{array}$} & $\begin{array}{l}\text { unitary } \\
\text { (4 items) }\end{array}$ & $\begin{array}{l}\text { ate chicken nuggets } \\
\text { jogged along the river } \\
\text { starred at us } \\
\text { watched the farmers at work }\end{array}$ \\
\hline & & $\begin{array}{l}\text { habitual } \\
\text { (4 items) }\end{array}$ & $\begin{array}{l}\text { practiced yoga } \\
\text { stayed home } \\
\text { played games } \\
\text { picnicked }\end{array}$ \\
\hline & \multirow{2}{*}{$\begin{array}{l}\text { Past } \\
\text { Progressive }\end{array}$} & $\begin{array}{l}\text { process } \\
\text { ( } 4 \text { items) }\end{array}$ & $\begin{array}{l}\text { were eating } \\
\text { was waiting for his girlfriend } \\
\text { was sawing logs } \\
\text { was hiking in a forest }\end{array}$ \\
\hline & & $\begin{array}{l}\text { habitual } \\
\text { (4 items) }\end{array}$ & $\begin{array}{l}\text { was biking every single day } \\
\text { was running every morning at } 6 \text { a.m. } \\
\text { was always studying hard } \\
\text { was often snacking }\end{array}$ \\
\hline State & $\begin{array}{l}\text { Past } \\
\text { simple }\end{array}$ & $\begin{array}{l}\text { unitary } \\
\text { (6 items) }\end{array}$ & $\begin{array}{l}\text { wanted to stay in his room } \\
\text { remained in his room } \\
\text { seemed like he was sick } \\
\text { was not a very enjoyable trip } \\
\text { understood nothing } \\
\text { remembered its way }\end{array}$ \\
\hline
\end{tabular}

The 8 distractors target other forms (i.e., present simple, present progressive, present perfect, past perfect), as demonstrated in Table 6.

Table 6. Distractors

\begin{tabular}{ll}
\hline Tense-aspect & Verb Phrase \\
\hline Present simple & washes the car, remembers the trip \\
Present progressive & is raining, is hoping \\
Present perfect & has known Jack, has studied agriculture \\
Past perfect & had left, had closed \\
\hline
\end{tabular}

The target for each item was determined by the native speaker responses. Sample test items are given below. 
1). My mom and I wanted to get some new clothes so we went shopping yesterday. While my mom (walk) to a fitting room, a stranger__(stare) at us. Then he looked around while my mom (try on) a jacket. It (seem) __ like he was sick because he (cough) anything. My mom, however, (buy) __ the jacket. all the time. I was annoyed and did not want to buy

2). Last week Phil read a book about pigeons. Although he (understand) (write) a paper about Richard's pigeon which (remember) straight line in the last year's race. Actually as the pigeon (reach) n__ nothing about species of birds, he couldn't do anything.

To ensure that the target EFL learner groups could inflect verbs that were provided in their base form according to the context of the sentence, a pilot study was carried out with 15 undergraduate students at Silpakorn University whose English language proficiency was approximately the same as that of the learner group to be tested in the final stage. Based on the results of the pilot study, a few items were revised. Specifically, the items with a non $3^{\text {rd }}$ person singular subject were changed into the $3^{\text {rd }}$ person singular subject. This makes it possible to have base form (e.g., walk) and present simple form (e.g., walks) as separate nontarget forms when coding for verbal morphology.

\subsection{Analysis}

Data from the 5 groups of Thai EFL learners were analyzed quantitatively with mean scores (Note 1). All verbs were coded for verbal morphology to yield the percentage of use of simple past, past progressive, and other forms with respect to the proficiency level and lexical aspectual class.

\section{Results}

In this section, results of the study are presented. To begin with, the use of simple past and past progressive according to proficiency levels are presented. Then, the use of simple past and past progressive according to lexical aspectual classes are reported. Finally, it will be demonstrated what other nontarget forms are used.

\subsection{Use of Simple Past and Past Progressive Morphology According to Proficiency Level}

An examination of simple past and past progressive morphology use across proficiency levels revealed that learners in the higher proficiency groups use the tense-aspect morphology more accurately than learners in the lower proficiency groups. Additionally, a comparison within a proficiency group showed that learners use simple past morphology more accurately than past progressive morphology. Table 7 illustrates the percentage of appropriate use of simple past and past progressive morphology by proficiency levels.

Table 7. Learners' appropriate use of simple past and past progressive morphology

\begin{tabular}{|c|c|c|c|c|c|c|c|c|c|c|}
\hline \multirow{3}{*}{$\begin{array}{l}\text { Tense-aspect } \\
\text { morphology }\end{array}$} & \multicolumn{2}{|l|}{ Gr. 1} & \multicolumn{2}{|l|}{ Gr. 2} & \multicolumn{2}{|l|}{ Gr. 3} & \multicolumn{2}{|l|}{ Gr. 4} & \multicolumn{2}{|l|}{ Gr. 5} \\
\hline & \multicolumn{2}{|c|}{ Mean (\%) } & \multicolumn{2}{|c|}{ Mean (\%) } & \multicolumn{2}{|c|}{ Mean (\%) } & \multicolumn{2}{|c|}{ Mean (\%) } & \multicolumn{2}{|c|}{ Mean (\%) } \\
\hline & 87.50 & \pm 6.92 & 81.92 & \pm 5.87 & 66.92 & \pm 17.44 & 56.73 & 8.54 & 43.08 & \pm 3.87 \\
\hline Past Progressive & 86.14 & \pm 6.51 & 74.77 & \pm 10.58 & 61.14 & \pm 5.41 & 53.86 & 5.95 & 36.82 & \pm 7.51 \\
\hline Total & 86.88 & \pm 5.37 & 78.65 & \pm 6.19 & 64.27 & \pm 8.79 & 55.42 & 5.38 & 40.21 & \pm 5.53 \\
\hline
\end{tabular}

\subsection{Use of Simple Past and Past Progressive Morphology According to Lexical Aspectual Class}

Lexical aspect was found to play an important role in tense-aspect marking. As shown in Table 8, the percentages of appropriate use of tense-aspect morphology vary according to lexical aspectual classes. For all groups, the use of simple past is greater with the [+punctual] predicates (i.e., achievement) than the [-punctual] predicates (i.e. accomplishment, activity and state). In contrast, the use of past progressive morphology is greater with the [-punctual] predicates (i.e. accomplishment and activity) than the [+punctual] predicates. In terms of telicity, for all groups, the use of simple past is greater with the [+telic] predicates (i.e., achievement, accomplishment) than the [-telic] predicates (i.e., activity and state). In contrast, the use of past progressive morphology is greater with the [-telic] predicates (i.e., activity) than the [+telic] predicates (i.e., achievement and accomplishment). 
Table 8. Learners' appropriate use of simple past and past progressive morphology across lexical aspectual classes

\begin{tabular}{|c|c|c|c|c|c|c|c|c|c|c|c|}
\hline \multirow{2}{*}{$\begin{array}{l}\text { Tense-aspect } \\
\text { morphology }\end{array}$} & \multirow{2}{*}{$\begin{array}{l}\text { Lexical } \\
\text { aspectual } \\
\text { class }\end{array}$} & \multicolumn{2}{|l|}{ Gr.1 } & \multicolumn{2}{|l|}{ Gr.2 } & \multicolumn{2}{|l|}{ Gr.3 } & \multicolumn{2}{|l|}{ Gr.4 } & \multicolumn{2}{|l|}{ Gr.5 } \\
\hline & & \multicolumn{2}{|c|}{ Mean (\%) } & \multicolumn{2}{|c|}{ Mean (\%) } & \multicolumn{2}{|c|}{ Mean (\%) } & \multicolumn{2}{|c|}{ Mean (\%) } & \multicolumn{2}{|c|}{ Mean (\%) } \\
\hline \multirow{4}{*}{$\begin{array}{l}\text { Simple } \\
\text { past }\end{array}$} & Ach & 89.17 & \pm 8.16 & 83.33 & \pm 13.25 & 73.33 & \pm 20.52 & 64.17 & \pm 16.47 & 45.00 & \pm 13.36 \\
\hline & Acc & 88.33 & \pm 10.95 & 82.50 & \pm 11.41 & 69.17 & \pm 22.47 & 57.50 & \pm 14.78 & 44.17 & \pm 8.16 \\
\hline & Act & 87.50 & \pm 12.82 & 81.25 & \pm 19.66 & 67.50 & \pm 21.61 & 55.00 & \pm 15.39 & 43.75 & \pm 13.75 \\
\hline & Sta & 85.83 & \pm 12.42 & 81.67 & \pm 17.85 & 60.83 & \pm 18.95 & 54.17 & \pm 11.94 & 40.83 & \pm 10.08 \\
\hline \multirow{3}{*}{$\begin{array}{l}\text { Past } \\
\text { progressive }\end{array}$} & Ach & 85.00 & \pm 15.50 & 74.38 & \pm 17.00 & 55.00 & \pm 11.03 & 50.63 & \pm 10.32 & 34.38 & \pm 12.74 \\
\hline & Acc & 89.17 & \pm 9.79 & 77.50 & \pm 9.49 & 69.17 & \pm 13.55 & 57.50 & \pm 13.67 & 40.83 & \pm 13.76 \\
\hline & Act & 90.00 & \pm 14.75 & 82.50 & \pm 14.43 & 73.75 & \pm 13.69 & 61.25 & \pm 15.04 & 42.50 & \pm 18.74 \\
\hline
\end{tabular}

$($ Ach $=$ achievement; Acc $=$ accomplishment; Act $=$ activity; Sta $=$ state $)$.

Furthermore, drawing a comparison between the use of simple past morphology with the [+dynamic, -telic, -punctual] predicates (i.e. activity) in the unitary past (e.g., starred at us) and habitual past (e.g., always practiced yoga), the study revealed that for all groups, the average scores of the unitary past are higher than those of the habitual past. This is demonstrated in Table 9.

Table 9. Learners' appropriate use of simple past morphology with activity verbs in different aspectual readings

\begin{tabular}{|c|c|c|c|c|c|c|c|c|c|c|}
\hline \multirow{2}{*}{$\begin{array}{l}\text { Aspectual } \\
\text { reading }\end{array}$} & \multicolumn{2}{|c|}{$\begin{array}{l}\text { Gr.1 } \\
\text { Mean (\%) }\end{array}$} & \multicolumn{2}{|c|}{$\begin{array}{l}\text { Gr.2 } \\
\text { Mean (\%) }\end{array}$} & \multicolumn{2}{|c|}{$\begin{array}{l}\text { Gr.3 } \\
\text { Mean (\%) }\end{array}$} & \multicolumn{2}{|c|}{$\begin{array}{l}\text { Gr.4 } \\
\text { Mean (\%) }\end{array}$} & \multicolumn{2}{|c|}{$\begin{array}{l}\text { Gr.5 } \\
\text { Mean (\%) }\end{array}$} \\
\hline & 87.50 & \pm 12.82 & 81.25 & \pm 19.66 & 67.50 & \pm 21.61 & 55.00 & \pm 15.39 & 43.75 & \pm 13.75 \\
\hline Habitual & 86.25 & \pm 12.79 & 80.00 & \pm 17.51 & 62.50 & \pm 20.27 & 50.00 & \pm 20.77 & 41.25 & \pm 17.51 \\
\hline
\end{tabular}

As regards the be+-ing form, the use of be+-ing with achievement verbs in iterative reading was found to be relatively higher than in futurate reading. However, learners' use of be+-ing with achievement verbs is found to be lower than with [-punctual] verbs (i.e., accomplishment and activity) in process reading, as demonstrated in Table 10 .

Table 10. Learners' appropriate use of be+-ing in different aspectual readings

\begin{tabular}{lllllllllll}
\hline \multirow{2}{*}{$\begin{array}{l}\text { Aspectual } \\
\text { reading }\end{array}$} & \multicolumn{3}{l}{ Gr.1 } & \multicolumn{3}{l}{ Gr.2 } & \multicolumn{3}{l}{ Gr.3 } & \multicolumn{3}{l}{ Gr.4 } & \multicolumn{3}{l}{ Gr.5 } \\
\cline { 2 - 12 } Mean (\%) & \multicolumn{2}{l}{ Mean (\%) } & \multicolumn{2}{l}{ Mean (\%) } & \multicolumn{2}{l}{ Mean (\%) } & \multicolumn{2}{l}{ Mean (\%) } \\
\hline Process & 89.58 & \pm 12.27 & 80.00 & \pm 12.11 & 71.46 & \pm 13.62 & 59.37 & \pm 14.35 & 41.66 & \pm 16.25 \\
Iterative & 86.25 & \pm 15.04 & 75.00 & \pm 16.73 & 56.25 & \pm 14.43 & 52.00 & \pm 16.99 & 35.00 & \pm 18.74 \\
Futurate & 83.75 & \pm 16.73 & 73.75 & \pm 19.36 & 53.75 & \pm 17.51 & 48.75 & \pm 18.50 & 33.75 & \pm 26.95 \\
\hline
\end{tabular}

In addition, for all groups, the use of be+-ing with an activity verb in habitual reading is lower than in process reading. This is demonstrated in Table 11.

Table 11. Learners' appropriate use of be+-ing with activity verbs in different aspectual readings

\begin{tabular}{llllllllll}
\hline \multirow{2}{*}{$\begin{array}{l}\text { Aspectual } \\
\text { reading }\end{array}$} & Gr.1 & \multicolumn{3}{l}{ Gr.2 } & \multicolumn{2}{l}{ Gr.3 } & \multicolumn{2}{l}{ Gr.4 } & \multicolumn{3}{l}{ Gr.5 } \\
\hline
\end{tabular}




\subsection{Use of Other Nontarget Forms in Past Contexts}

As shown by Table 12, the 5 groups exhibit varying proportions of using the nontarget forms. For groups 3,4 and 5, base form (e.g., my mom buy the jacket) is the most dominant form, compared to other nontarget forms in context where simple past would be required. For groups 1 and 2, however, present perfect (e.g., my mom has bought the jacket) is most frequently used.

Table 12. Learners' use of nontarget forms in context where past simple is required

\begin{tabular}{llllll}
\hline \multirow{2}{*}{ Nontarget forms } & Gr.1 & Gr.2 & Gr.3 & Gr.4 & Gr.5 \\
\cline { 2 - 6 } & Mean (\%) & Mean (\%) & Mean (\%) & Mean (\%) & Mean (\%) \\
\hline Base & 0 & 1.10 & 16.20 & 22.51 & 28.94 \\
Present simple & 0.75 & 2.66 & 4.21 & 9.06 & 10.51 \\
Present progressive & 2.06 & 3.58 & 5.60 & 4.22 & 3.90 \\
Present perfect & 3.68 & 4.68 & 1.30 & 1.06 & 0.71 \\
Past progressive & 2.44 & 2.00 & 1.54 & 1.28 & 0.28 \\
Past perfect & 3.57 & 4.06 & 1.20 & 0.66 & 0.14 \\
Other nonfinite forms & 0 & 0 & 3.03 & 4.48 & 13.40 \\
\hline
\end{tabular}

On the other hand, in context where past progressive would be required, group 4 and 5 , frequently use nonfinite forms in addition to the base form, as shown in Table 13. Most of the nonfinite forms, however, were found in the form of gerund (e.g., he coughing all the time) rather than to-infiitive (e.g., he to cough all the time).

Table 13. Learners' use of nontarget forms in context where past progressive is required

\begin{tabular}{llllll}
\hline \multirow{2}{*}{ Nontarget forms } & Gr.1 & Gr.2 & Gr.3 & Gr.4 & Gr.5 \\
\cline { 2 - 6 } & Mean (\%) & Mean (\%) & Mean (\%) & Mean (\%) & Mean (\%) \\
\hline Base & 0 & 1.68 & 4.93 & 8.71 & 14.41 \\
Present simple & 1.60 & 2.53 & 4.01 & 7.93 & 12.40 \\
Present progressive & 3.55 & 3.82 & 13.11 & 6.94 & 10.92 \\
Present perfect & 2.01 & 4.19 & 3.08 & 2.99 & 2.35 \\
Simple past & 5.52 & 7.74 & 6.22 & 4.53 & 3.53 \\
Past perfect & 1.18 & 3.55 & 2.85 & 2.27 & 1.22 \\
Other nonfinite forms & 0 & 1.72 & 4.66 & 12.77 & 18.35 \\
\hline
\end{tabular}

\section{Discussion}

With respect to the research questions mentioned earlier, this section starts with a discussion on the development of L2 tense-aspect marking. Then the roles of lexical aspect in L2 tense-aspect marking will be discussed. Finally, an argument for $\mathrm{L} 1$ influence on $\mathrm{L} 2$ tense-aspect marking will be provided.

\subsection{The Development of L2 Tense-Aspect Marking}

That learners in the higher proficiency groups outperformed those in the lower proficiency groups in terms of tense-aspect marking is consistent with results from several earlier studies. For instance, in Sriphrom and Ratithamkul's (2014) study of lexical aspect and the use of simple past tense by Thai learners of English, it was found that the learners in the high proficiency groups used the past tense form more correctly that the learners in the low proficiency group. In Sriphrom's (2014) study of development of the relationship between tense forms and temporal-aspectual meanings in English in relating past events by Thai learners, he also found that the learners used tense forms more accurately and more variably as their proficiency increased. In Robinson's (1995) cross-sectional study of tense and aspect marking in interlanguage, it was also found that the association of inflections with tense increase with proficiency level; lower-level learners associate past morphology primarily with lexical aspect; higher learners primarily with tense. Similarly in the study by Bardovi-Harlig and Reynold's (1995) study, it was also observed that higher level learners outperform lower level learners with respect to 
tense-aspect inflection (Note 2).

Additionally, that the correct use of simple past exceed that of past progressive could possibly be resulted from the morphological difference between the two. The progressive aspect is expressed by a discontinuous morpheme (Plag, 2002: 24) consisting of 2 separate parts (i.e. the auxiliary be and the suffix -ing) whereas most of the simple past form involves only the addition of the suffix - $d /$-ed to the verb. Consequently, as discussed by Sriphrom (2014), the past progressive involves a complex form, compared to the simple past morphology. The past progressive, therefore, is relatively harder to master, especially for beginners.

\subsection{The Roles of Lexical Aspect in L2 Tense-Aspect Marking}

The results of the present study are consistent with the Aspect Hypothesis and in agreement with findings from Robinson (1995), Bardovi-Harlig and Reynolds (1995), Bardovi-Harlig's (1998) and Sriphrom (2014). To illustrate, in Robinson's (1995) cross-sectional study of tense and aspect marking in interlanguage, it was found that progressive marking is associated with activities whereas past tense is associated with telic verb. Similarly, Bardovi-Harlig and Reynolds (1995), found that learners were more accurate in providing the target past tense morphology for achievement and accomplishments as opposed to statives and activities. With respect to the progressive, the predicted association between progressive marking and activities was found. In the same line, Bardovi-Harlig (1998), analyzing learners' oral narratives, found that learners used the simple past morphology with achievement verbs significantly more than accomplishment verbs. As regards the progressive, the predicted association between progressive marking and activities was found. Additionally, in the study conducted by Sriphrom (2014), the distribution of the simple past form in the narratives was also found to conform the Aspect Hypothesis.

Andersen (1993) suggests an interpretation for the findings with respect to the effects of inherent semantic properties of the predicate on tense-aspect marking. He suggests that learners follow 2 general principles in matching verb inflections with particular verbs: the Relevance Principle (Bybee, 1985; Slobin, 1985) and The One-to-one Principle (Andersen, 1984). According to the Relevance Principle a grammatical morpheme is used by learners according to how congruent the meaning of the morpheme is with the meaning of the lexical item to which it is attached. Simultaneously, the One-to-one Principle guides the learners to assume that each grammatical morpheme they discover has one and only one meaning, function, and distribution. Thus, learners will assign a more conservative form-meaning relation to a morpheme than fully proficient native speakers (as cited in Andersen \& Shirai, 1996: 554).

Additionally, the use of tense-aspect morphology, as demonstrated in Table 10 and Table 11 is consistent with Taylor's (1989) idea of treating tense and aspect morphology as a prototype category. As demonstrated in Table 11, learners' appropriate use of simple past with activity verbs in the unitary past (e.g., starred at us) is remarkably higher than in the habitual past (e.g., always practiced yoga). Similarly, learners' appropriate use of be+-ing with activity verbs in the habitual reading (e.g., was biking every single day) is considerably lower than in the process reading (e.g., was waiting for his girlfriend), as demonstrated in Table 11. This suggests that in learning a category, the learners acquire prototypical members first, then gradually extend the scope to marginal members. According to Brown (1973: 319), this involves the notion of markedness. While the process meaning is unmarked, iterative and habitual meanings are regarded as marked categories which usually emerge relatively late in tense-aspect acquisition. Of the two however, the iterative progressive is less marked because it also has the action-in-progress meaning, the only difference being the ongoing action is 'repeated.'

\subsection{L1 Influence on L2 Tense-Aspect Marking}

For lack of tense-aspect inflection in L1, lower proficiency learners overuse uninflected form, as evidenced by the high percentage of use of base form in group 4 and 5. That the low proficiency learners use uninflected base form in past contexts was also reported in several previous studies. For instance, Yang and Huang (2004) discussed that due to the absence of grammatical tense in L1, low proficiency learners rely more on pragmatic and lexical devices than on grammatical devices in expressing temporality in L2. Additionally, in Wang's (2012) study of the acquisition of English tense and agreement morphology by L1 Malay and L1 Chinese learners of English, the lower proficiency learners were found to have difficulty with tense and agreement morphology since the Chinese and Malay languages do not have overt tense or agreement morphology.

Even more crucial in supporting L1 influence on L2 tense-aspect marking is the learners' incorrect use of perfect form in definite past contexts. As mentioned earlier, English and Thai differ in how definite and indefinite past are expressed. English distinguishes between indefinite past -expressed by present perfect (e.g., she has graduated) and the definite past -expressed by the simple past (e.g., she graduated in 2002) -whereas Thai expresses both pasts with the tense-aspect marker laew. This could possibly lead Thai EFL learners to overuse 
the present perfect in contexts where the simple past would be required. This is congruent with the findings in Collins' (2002) study in which French learners of English are found to overuse the present perfect. It was discussed that the overuse of present perfect was due to the passé composé being used to express both the indefinite and definite pasts in French. However, the frequency of the present perfect form was not necessarily greatest in the lowest-level group. The perfect was more frequent among learners who had acquired a certain level of productive use of simple past. Accordingly, it was suggested that L1 influence is constrained by L2 development (Collins, 2002: 60).

\section{Conclusion}

Drawing distinctions of aspectual reading associated with each past morphology, the present study investigates how the use of simple past and past progressive morphology change as learners become more proficient in their target language and to what extent lexical aspectual class and L1 influence the use of simple past and past progressive morphology. Employing a cloze task as a data elicitation tool, this study revealed that learners' correct use of past morphology increases as they become more proficient in their target language. Lexical aspect, however, was found to play an important role in tense-aspect marking even among students at more advanced stages of learning. Additionally, the investigation into the use of each past morphology in different aspectual readings points to the marked nature of iterative, futurate and habitual meanings. As regards L1 influence on L2 tense-aspect marking, learners' use of L1 influenced form varies according to their L2 proficiency level, suggesting that L1 influence is constrained by L2 development.

Researching into L2 tense-aspect, this study brings to light some implications for instruction of L2 tense-aspect system.That the learners first associate simple past morphology with only achievement verbs and past progressive morphology with only activity verbs can be attributed to undergeneralization in the learner grammar. According to Bardovi-Harlig and Reynolds (1995: 121) and Schmidt (1990,1992) positive evidence with noticing exercises is helpful in expanding undergeneralization in learners' grammar. Once the learners notice a difference between the input (i.e., positive eveidence) and their own production, they can revise their interlanguage rules (Schmidt, 1990, 1992).

The scope of the present study suggests several possibilities for future research. This study focused on L1 transfer and lexical aspect. The two, however, are not the only variables to account for the L2 development of tense-aspect. Assuming Salaberry (2008), in addition to L1 transfer and lexical aspect that act as independent variables to account for the L2 development of tense-aspect, other variables are discourse structure, syntactic structure and perceptual saliency. Future research on the acquisition of the L2 tense-aspect system therefore might investigate the roles these factors could play. Additionally, in designing a method to investigate the acquisition of L2 tense-aspect, future research should take into account factors such as type of data and data collection procedures (Salaberry \& Comajoan, 2013: 432). Furthermore, the effect of learning environment, type of input and subject-related factors (e.g., level of exposure to the target language and motivation) should also be taken into consideration. Direct control over these factors as part of research design, however, awaits future L2 tense-aspect research.

\section{References}

Andersen, R. W. (1991). Developmental sequences: The emergence of aspect marking in second language acquisition. In T. Huebner, \& C. A. Ferguson (Eds.), Crosscurrents in second language acquisition and linguistic theories (pp. 305-324). Amsterdam: Benjamins. https://doi.org/10.1075/lald.2.17and

Andersen, R. W., \& Shirai, Y. (1996). The primacy of aspect in the first and second language acquisition: The Pidgin/Creole connection. In W. C. Ritchie, \& T. K. Bhatia (Eds.) Handbook of second language acquisition (pp. 527-570). San Diago, CA: Academic Press. https://doi.org/10.1016/B978-012589042-7/50018-9

Antinucci, F., \& Miller, R. (1976). How children talk about what happened. Journal of Child Language, 3, 167-189. https://doi.org/10.1017/S0305000900001434

Ayoun, D., \& Salaberry, R. (2008). Acquisition of English tense-aspect morphology by advanced French instructed learners. Language learning, 58(3), 555-595. https://doi.org/10.1111/j.1467-9922.2008.00450.x

Bachman, L. (1990). Fundamental considerations in language testing. Oxford: Oxford University Press.

Bardovi-Harlig, K., \& Bergeström, A. (1996). The acquisition of tense and aspect in SLA and FLL: A study of learner narratives in English (SL) and French (FL). Canadian Modern Language Review, 52, 308-330. https://doi.org/10.3138/cmlr.52.2.308 
Bardovi-Harlig, K. (1992). The relationship between form and meaning: a cross-sectional study of tense and aspect in the interlanguage of learners of English as a second language. Applied Psycholinguistics, 13, 253-278. https://doi.org/10.1017/S0142716400005634

Bardovi-Harlig, K. (1998). Narrative structure and lexical aspect: Conspiring factors in second language acquisition of tense-aspect morphology. Studies in Second Language Acquisition, 20, 471-508. https://doi.org/10.1017/S0272263198004021

Bardovi-Harlig, K., \& Reynolds, D. W. (1995). The role of lexical aspect in the acquisition of tense and aspect. TESOL Quarterly, 29, 107-131. https://doi.org/10.2307/3587807

Bayley, R. (1991). Variation in interlanguage tense marking. Paper presented at the annual meeting of the Linguistic Society of America, Chicago.

Bayley, R. (1994). Interlanguage variation and the quantitative paradigm: Past tense marking in Chinese-English. In E. E. Tarone, S. M. Gass, \& A. D. Cohen (Eds.), Research methodology in second-language acquisition (pp. 157-181). Hillsdale, NJ: Erlbaum.

Boonyapatipark, T. (1983). A study of aspect in Thai. Unpublished doctoral dissertation, University of London.

Brown, R. (1973). A first language: The early stages. Cambridge, MA: Harvard University Press. https://doi.org/10.4159/harvard.9780674732469

Chiravate, B. (2002). Syntactic and semantic properties of aspectual markers in Thai. Unpublished doctoral dissertation, Michigan State University.

Chiravate, B. (2012). The effects of motivation and proficiency on pragmatic and grammatical awareness in foreign language learning. In W. M. Chan, K. N. Chin, S. K. Bhatt, \& I. Walker (Eds.), Perspectives on Individual Characteristics and Foreign Language Education (pp. 93-113). Berlin: Walter de Gruyter. https://doi.org/10.1515/9781614510932.93

Collins, L. (1997). The development of tense and aspect. Paper presented at the Second Language Research Forum, Michigan: Michigan State University.

Collins. L. (2002). The role of L1 influence and lexical aspect in the acquisition of temporal, Language Learning, 52(1), 43-94. https://doi.org/10.1111/1467-9922.00177

Comrie, B. (1976). Aspect. Cambridge: Cambridge University Press.

Dittmar, N. (1981). On the verbal organization of L2 tense marking in an elicited translation task by Spanish immigrants in Germany. Studies in second language acquisition, 3, 136-164. https://doi.org/10.1017/S0272263100004149

Gabriele. A. (2005). The acquisition of aspect in a second language: a bidirectional study of learners of English and Japanese. Unpublished doctoral dissertation, The City University of New York.

Gabriele, A. (2009). Transfer and transition in the SLA of aspect. Studies in Second Language Acquisition, 31, 371-402. https://doi.org/10.1017/S0272263109090342

Giacalone-Ramat, A. (1990). The acquisition of temporality: A second language perspective. Folia Linguistica, XXIV/3-4, 405-428. https://doi.org/10.1515/flin.1990.24.3-4.405

Housen, A. (2002). The development of tense-aspect in English as a second language and the variable influence of inherent aspect. In M. Salaberry, \& Y. Shirai (Eds.), Tense-aspect morphology in L2 acquisition. Amsterdam: John Benjamins. https://doi.org/10.1075/lald.27.09hou

Kumpf, L. (1984). Temporal systems and universality in interlanguage: A case study. In F. Eckman, L. Bell, \& D. Nelson (Eds.), Universals of Second Language Acquisition. MA: Newbury House.

Meepoe, T. (1996). Imperfectivity in Thai: the distinction between kamlang and yuu. Unpublished master thesis, University of California, Los Angeles.

Plag, I. (2003). Word-Formation in English. Cambridge: Cambridge University Press. https://doi.org/10.1017/CBO9780511841323

Robinson, R. (1990). The primacy of aspect: Aspectual marking in English interlanguage. Studies in Second Language Acquisition, 12, 315-330. https://doi.org/10.1017/S0272263100009190

Robinson, R. (1993). Aspectual marking in English interlanguage: A cross-sectional study. Unpublished doctoral dissertation, University of California, Los Angeles. 
Robinson, R. (1995). The aspect hypothesis revisited: a cross-sectional study of tense and aspect marking in interlanguage. Applied Linguistics, 16, 344-370. https://doi.org/10.1093/applin/16.3.344

Rohde, A. (1996). The aspect hypothesis and emergence of tense distinctions in naturalistic L2 acquisition. Linguistics, 34, 1115-1137. https://doi.org/10.1515/ling.1996.34.5.1115

Rohde, A. (2002). The aspect hypothesis in naturalistic L2 acquisition: What uninflected and non-target-like verb forms in early interlanguage tell us. In R. Salaberry, \& Y. Shirai (Eds.), Tense-aspect morphology in L2 acquisition (pp. 199-220). Amsterdam: John Benjamins. https://doi.org/10.1075/lald.27.10roh

Salaberry, R. (1997). The development of past tense aspect among adult academic L2 learners.Unpublished doctoral dissertation, Cornell University.

Sato, C. J. (1990). The syntax of conversation in interlanguage development. Tübingen: Narr.

Schmidt, R. (1990). Consciousness, Learning and interlanguage pragmatics. University of Hawaii Working Papers in Linguistics, 9, 213-243.

Schmidt, R. (1992). Awareness and second language acquisition. Annual Review of Applied Linguistics, 13, 206-226. https://doi.org/10.1017/S0267190500002476

Smith, C. S. (1991). The parameter of aspect. Dordrecht: Kluwer. https://doi.org/10.1007/978-94-015-7911-7

Smith, C. S., \& Weist, R. M. (1987). On the temporal contour of child language: A reply to Rispoli and Bloom. Journal of Child Language, 14, 387-392. https://doi.org/10.1017/S0305000900013003

Sriphrom, S. (2014). Development of the relationship between tense forms and temporal-aspectua meanings in English in relating past events by Thai learners. Unpublished doctoral dissertation, Chulalongkorn University.

Sriphrom, S., \& Ratitamkul, T. (2014). Lexical aspect and the use of past simple tense by Thai learners of English. Manusya, 17(1), 64-77.

Strazny, P. (Ed.) (2005). Aspect. In Encyclopedia of linguistics (Vol. 1, pp. 93-94). New York: Fitzroy Dearborn.

Strazny, P. (Ed.) (2005).Tense and aspect marking. In Encyclopedia of linguistics (Vol. 2, pp. 1088-1089). New York: Fitzroy Dearborn.

Taylor, J. R. (1989). Linguistic categorization: Prototype in linguistic theory. Oxford: Oxford University Press. https://doi.org/10.1515/ling.1989.27.4.663

Vendler, Z. (1967). Linguistics in Philosophy. Ithaca, NY: Cornell University Press.

Visonyanggoon, S. (2000). Parallelism between noun phrases and clauses in Thai. Ph.D. dissertation, Michigan State University.

Wang, B. E. (2012). Acquisition of English Tense and Agreement Morphology by L1 Malay and L1 Chinese speakers. 3L: Southeast Asian Journal of English language studies, 18(3), 5-14.

Weist, R. M., Wysocka, H., Witkowska-Standnik, K., Buczowska, E., \& Konieczna, E. (1984). The defective tense-hypothesis: On the emergence of tense and aspect in child Polish. Journal of Child Language, 11, 347-374. https://doi.org/10.1017/S030500090000581X

Wolfram, W. (1995). Variability in tense marking: A case for the obvious. Speech, 59, 31-50. https://doi.org/10.2307/454992

Yang, S., \& Huang, Y. (2004). The impact of the absence of grammatical tense in L1 on the acquisition of the tense-aspect system in L2. IRAL, 42, 49-70. https://doi.org/10.1515/iral.2004.002

\section{Notes}

Note 1. The two variables in this study are ordinal (group 1-5) and ratio scale (scores from the cloze test). Therefore, Pearson correlation cannot be used in analyzing the data.

Note 2. Language competence comprises grammatical (or organizational) and pragmatic competence (Bachman 1990). Compared to the pragmatic competence, the grammatical competence (e.g., tense-aspect marking) is more likely to increased concurrently with proficiency level (Chiravate, 2012). 


\section{Copyrights}

Copyright for this article is retained by the author(s), with first publication rights granted to the journal.

This is an open-access article distributed under the terms and conditions of the Creative Commons Attribution license (http://creativecommons.org/licenses/by/4.0/). 